Bangladesh J. Bot. 44(2): 163-175, 2015 (June)

\title{
PHYTOPLANKTON DIVERSITY IN DIGBOI OIL REFINERY EFFLUENT RECEIVING STREAM OF ASSAM, INDIA
}

\author{
Dhrubajyoti Bordoloi ANd PP BARUAH* \\ Department of Botany, Gauhati University, Guwahati-781014, Assam, India
}

Key words: Phytoplankton, Water quality, Oil refinery effluent, Digboi, Assam

\begin{abstract}
A comprehensive study was carried out to investigate phytoplankton community and water quality in the Digboi oil refinery effluent stream. Taxonomic composition, abundance, spatial distribution, temporal dynamics of phytoplankton were studied along with physicochemical properties of water based on monthly data collected from seven selected sampling stations during April, 2011 - March, 2012. Altogether 139 species (7 orders, 19 families, 67 genera) of phytoplankton were identified of which Bacillariophyceae was the dominant class with 45 species followed by Chlorophyceae 40, Cyanophyceae 34 and Euglenophyceae 20. Though distinct changes in community structure were reported, higher phytoplankton abundance revealed during the post monsoon months. Correlation analysis showed influence of phenol and total oil content (TOC) along with $\mathrm{pH}$, inorganic phosphorus and nitrate content in distribution and abundance of the phytoplankton.
\end{abstract}

\section{Introduction}

Phytoplankton are microscopic plants that grow in water bodies. They are very sensitive to slightest changes in environmental conditions of their habitat (Palmer 1959). Being located at the base level of energy transfer or trophic structure phytoplankton provide more accurate information on changing habitat characteristics compared to other aquatic lives (McCormick and Cairns 1994). Therefore, phytoplankton observation has been used as a reliable tool for biomonitoring of pollution in any aquatic bodies (Mathivanan et al. 2007). Digboi is the place in India where for the first time crude oil was explored in Asia during late 19th century and Digboi refinery is the oldest petroleum refinery in the subcontinent established in the year 1901. The refinery has been regularly discharging hazardous chemicals such as oil, hydrocarbon, phenol etc. to a natural stream that created a stress condition for growth of aquatic flora and fauna including phytoplankton. A little work has so far been done to understand the effect of petroleum refinery effluent on fresh water algal community in the region (Singh and Gaur 1988, Baruah et al. 2009). The present investigation was planned to undertake a study on diversity, distribution and abundance of phytoplankton community of effluent receiving stream of Digboi oil refinery (Assam), India in relation to water quality. Correlation between different water parameters and phytoplankton data were also studied to evaluate their interactions.

\section{Materials and Methods}

The study was conducted during April 2011 to March 2012. The effluents of the refinery are pushed out through an open drain named Telnala flowing through Digboi municipal area and discharged into a natural stream that originates from Digboi reserve forest and flows through paddy fields. Seven sampling stations (Fig. 1) were selected and designated as S1, S2, S3, S4, S5, S6 and S7. S1 station was the effluent receiving point of the drain. S2, S3 and S4 were about $500 \mathrm{~m}, 1 \mathrm{~km}$ and $2 \mathrm{~km}$ away from S1, respectively. S5 was the confluence of the effluent carrying

*Author for correspondence: < partha_ghy16@rediffmail.com>. 
drain (Telnala) and the natural stream. S6 was at 500 metre upstream and S7 was 500 meter downstream on the natural stream from the confluence point (S5). From each station phytoplankton and water samples were collected in three replicates in monthly intervals using Nansen sampler. Identification of phytoplankton samples were done by morphological observations consulting literature and monographs of Fritsch (1935, 1961), Smith (1950), Desikachary (1959), Ramanathan (1964), Prescott (1975), Gandhi (1998), Perumal and Anand (2009) and Yamagishi (2010). The physicochemical parameters, such as water temperature, $\mathrm{pH}$, conductivity, turbidity were measured on the spot using Systronics Digital Water Analyzer 371. $\mathrm{DO}$, free $\mathrm{CO}_{2}$, BOD, COD, inorganic phosphorus, nitrate, phenol and total oil content (TOC) were measured following APHA (2012). The abundance values were calculated under Sedgwick rafter plankton counting cell. The species with more than $75 \%$ frequency were designated as common, followed by frequent $(40-75 \%)$ and rare $(<40 \%)$, respectively. Pearson's correlation coefficients among the variables of water quality along with phytoplankton abundance were computed and analyzed using XLstat version 2013.5.

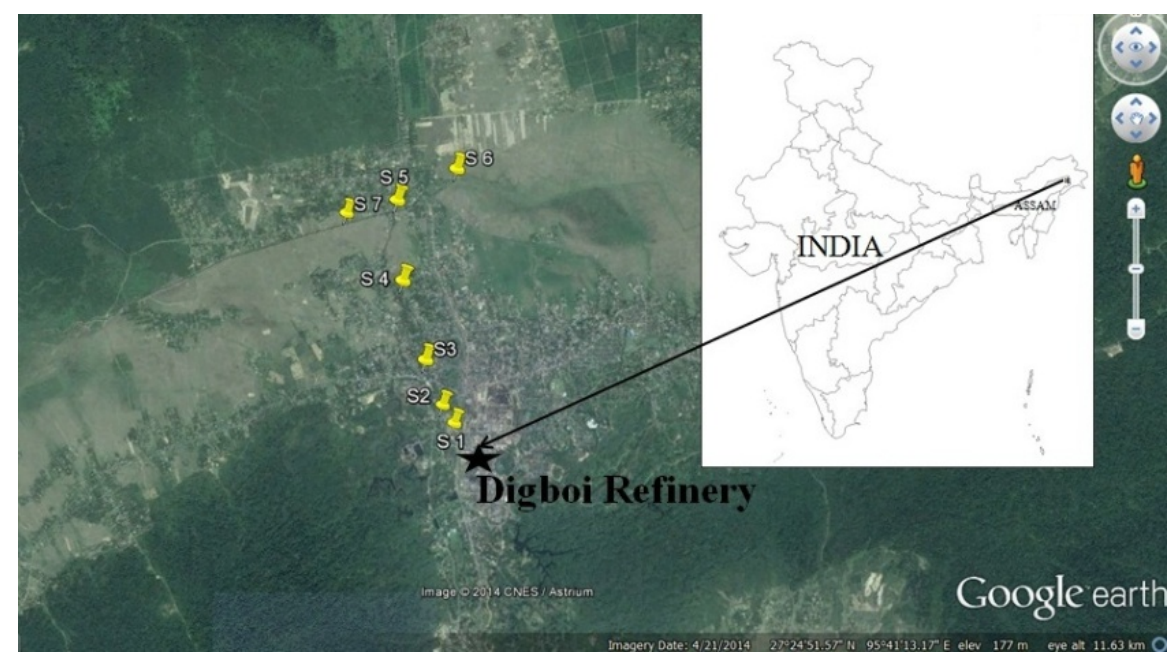

Fig 1. Location map of sampling stations along the Digboi refinery effluent stream.

\section{Results and Discussion}

The phytoplankton species recorded during the present endeavour are depicted in Table 1 along with their frequency of occurrence and abundance in different sampling stations. A total of 4 classes, 7 orders, 19 families, 67 genera and 139 species of phytoplankton were recorded from the Digboi oil refinery effluent receiving stream, which belonged to Cyanophyceae (17 genera, 34 species), Chlorophyceae (22 genera, 40 species), Euglenophyceae (8 genera, 20 species) and Bacillariophyceae (20 genera, 45 species).

The Bacillariophyceaean members were dominant in the Digboi refinery effluent receiving stream (Table 1). Kelly (1998) reported that Bacillariophycean dominance in an aquatic ecosystem is a major indicator of water quality and environmental condition as they are adapted to a wide range of physico-chemical parameters. Out of 20 Bacillariophyceaen genera recorded in the present study, 12 were Palmer's pollution tolerant genera (Palmer 1969). They were Melosira, Cyclotella, Fragilaria, Synedra, Achnanthes, Navicula, Pinnularia, Gomphonema, Cymbella, Nitzschia, Hantzschia and Suriella (Table 1) and they indicated higher pollution load (Atici and 


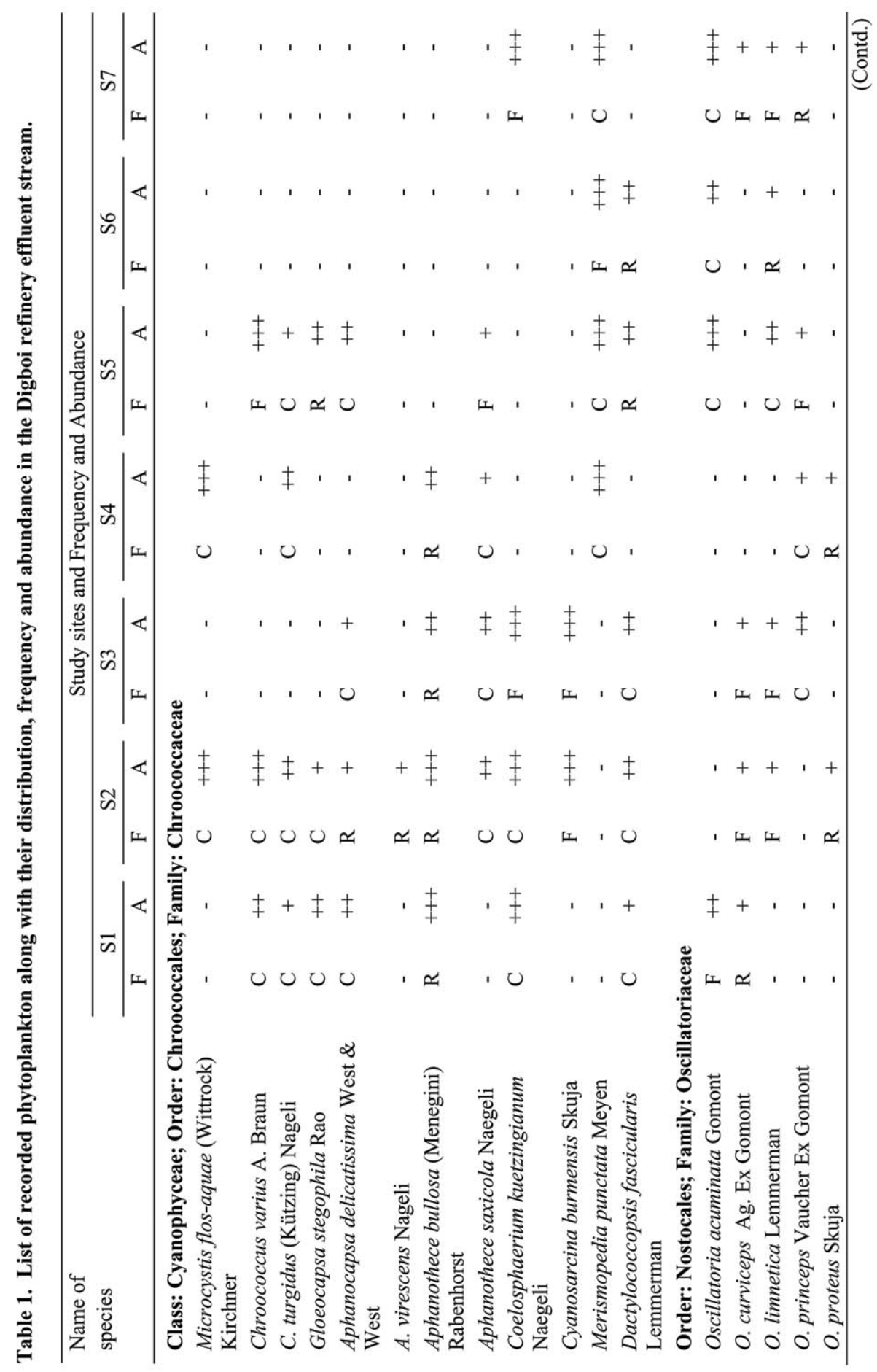




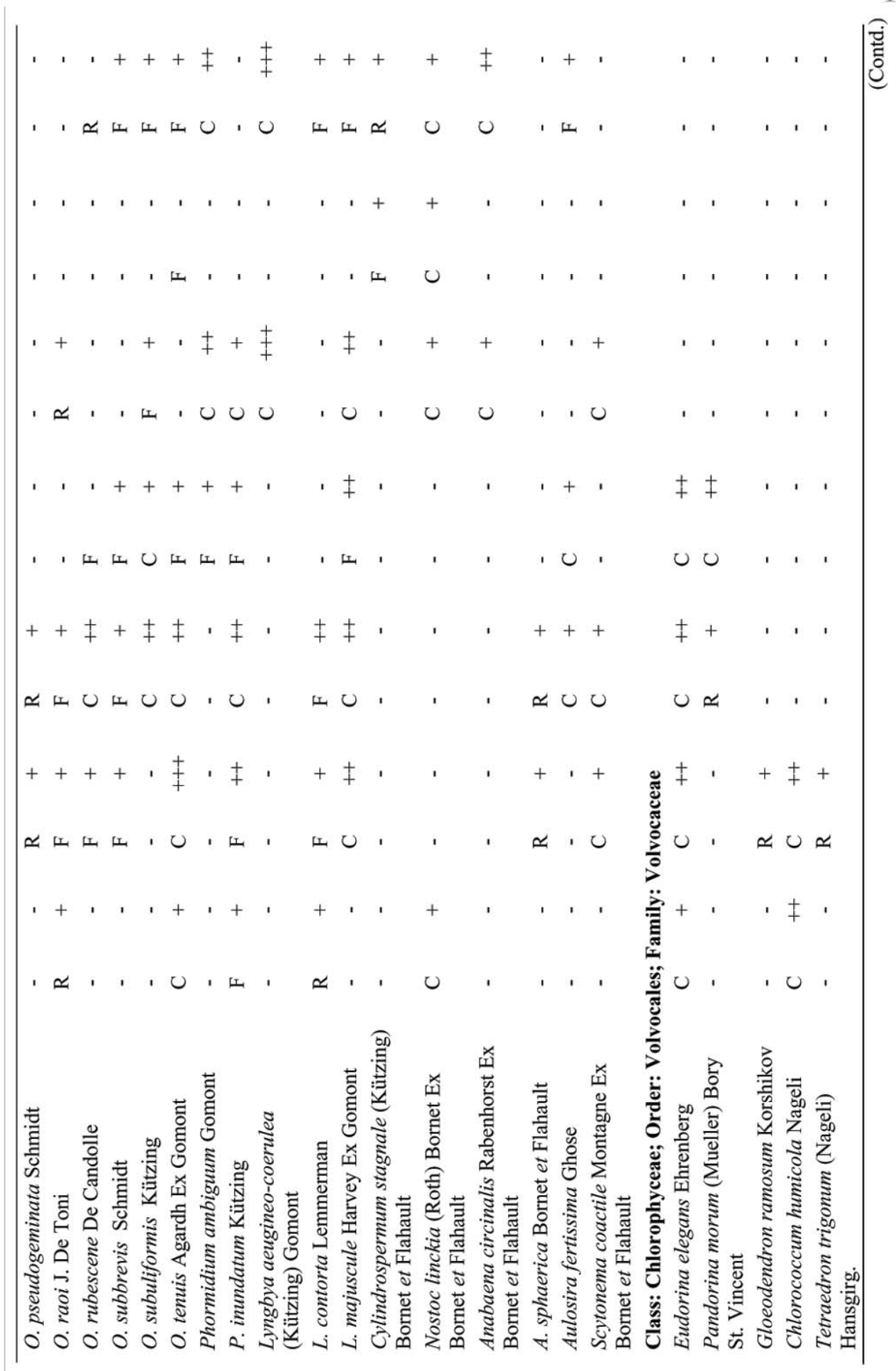




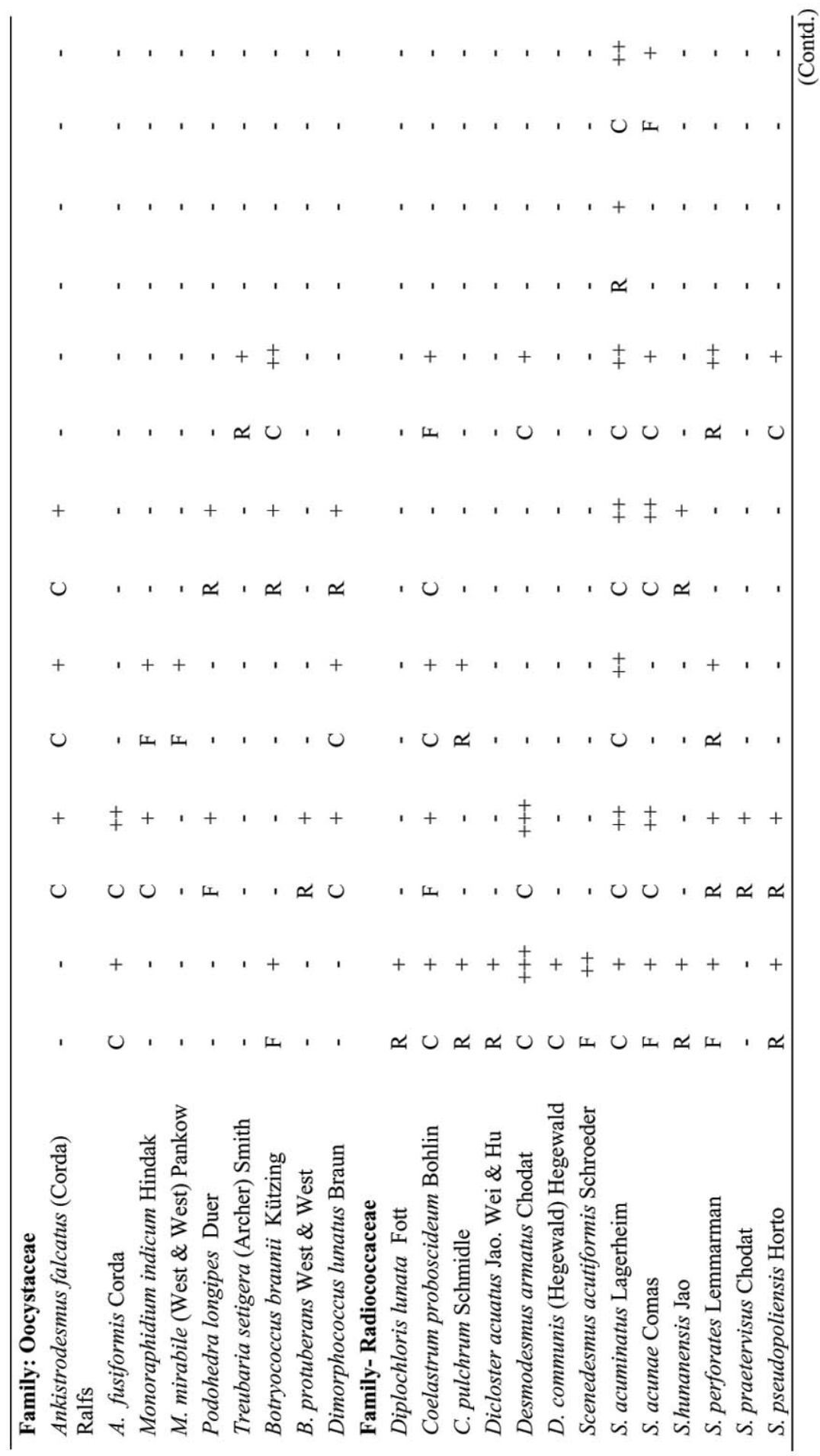




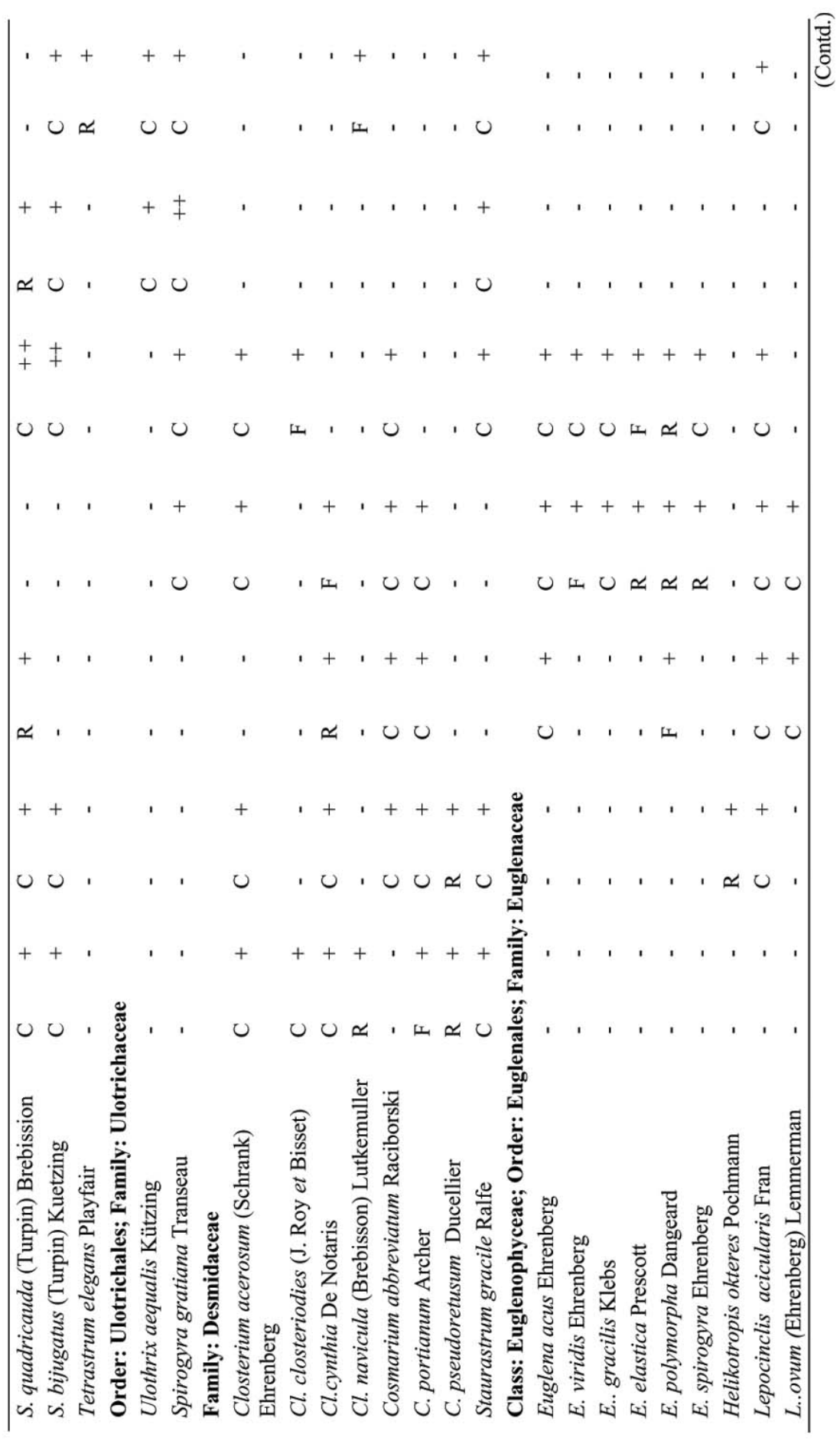




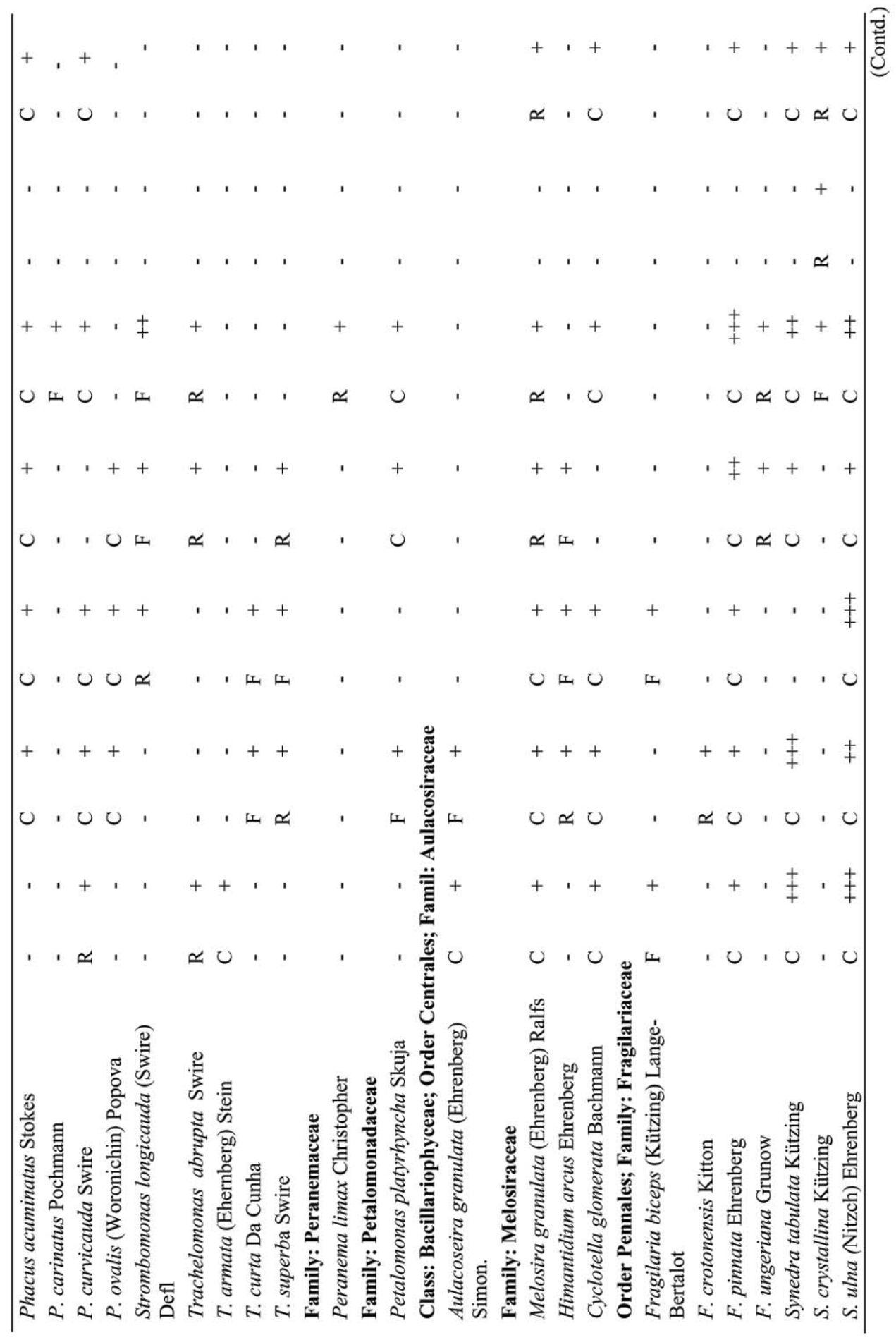




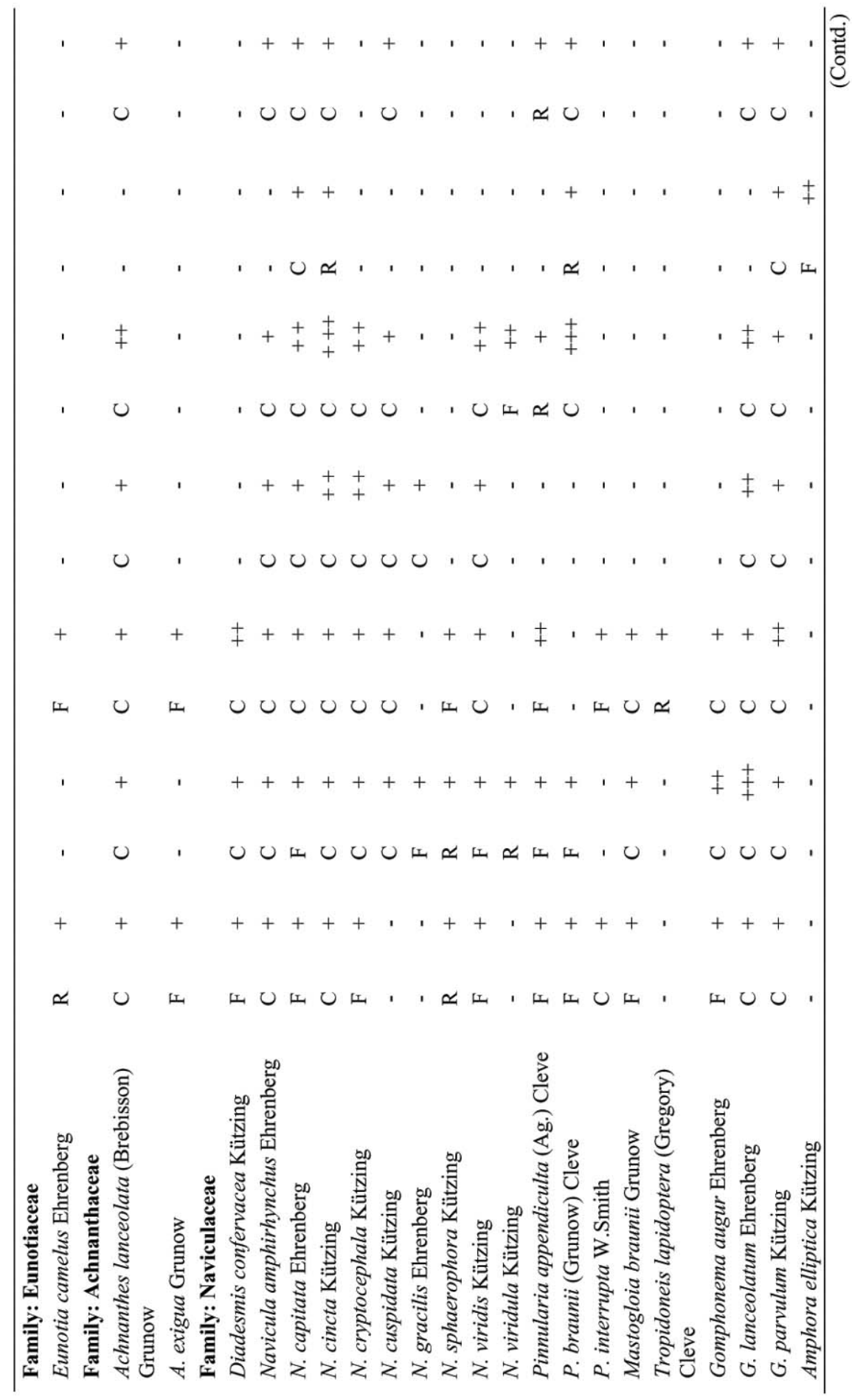




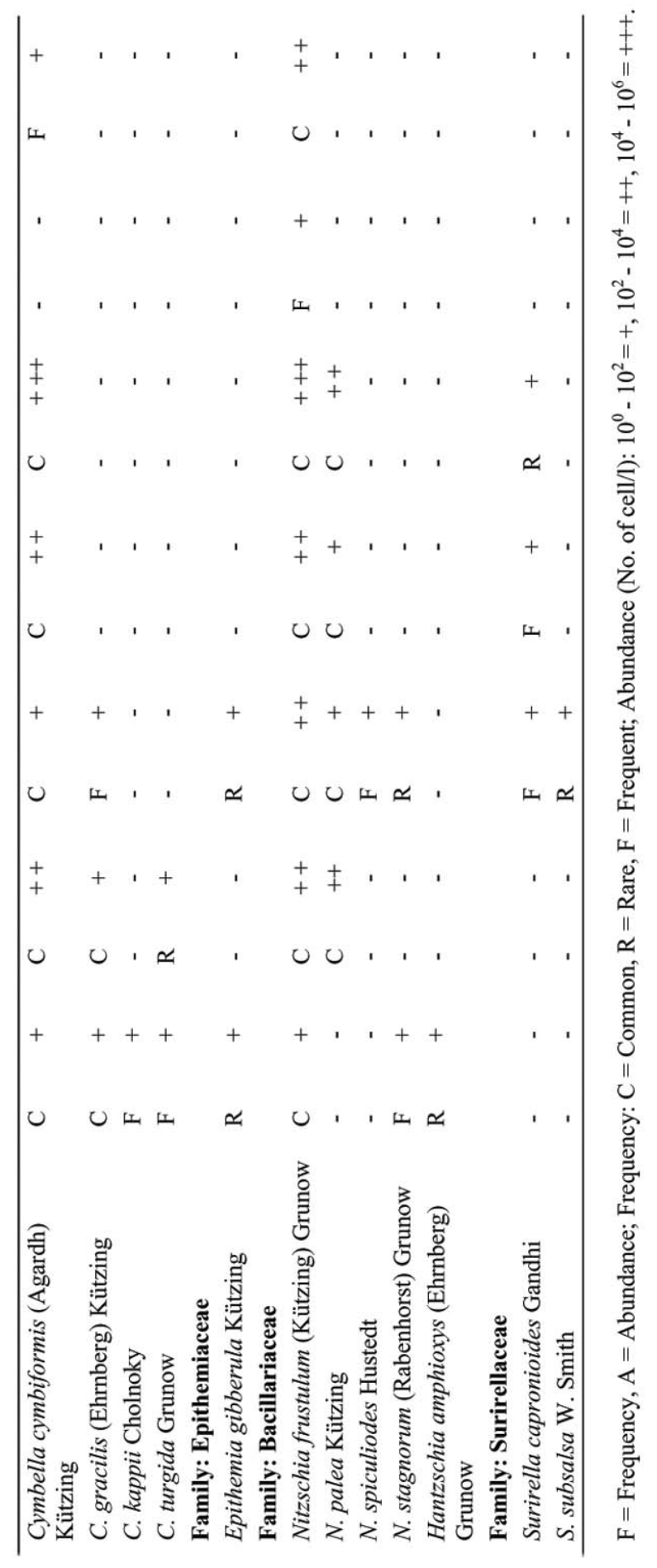


Obali, 2010) in the stream as a whole. Sampling stations along the effluent drain Telnala were highly infested with two pollution tolerant centric genera Melosira and Cyclotella, two species of Cymbella (C. cymbiformis and C. gracilis) and two Synedra species (S. tabulata and S. ulna) where total oil content was high.

Chlorophyceae was the second largest phytoplanktonic algal class as recorded in the stream in the present study. Scenedesmus was the dominant genus with nine species. Palmer's pollution tolerant Chlorophycean genera viz. Chlorococcum, Eudorina, Pandorina, Ankistrodesmus, Coelastrum and Scenedesmus were common in sampling sites S1 to S5 along the Telnala with moderate to high abundance (Table 1). Though desmids have low tolerance with regard to polluted water (Mahadev et al. 2010), 8 species belong to Closterium, Cosmarium and Staurastrum were found common in all the stations along the Telnala. Closterium and Cosmarium of the family Desmidaceae are reported to be pollution tolerant genera by Palmer (1969). Singh and Gaur (1989) also recorded desmids in oil refinery effluent receiving stream.

Among Cyanophyceae, the abundance of Microcystis flos-aquae, Chroococcus varius, Aphanothece bullosa, Coelosphaerium kuetzingianum, Cyanosarcina burmensis, Merismopedia punctata and Oscillatoria tenuis were recorded high at the sampling stations S1 to S4 which indicated their resistance capacity to refinery effluent. Only 20 taxa of Euglenophyceae were reported from the stream (Table 1). Highest congregation of Euglena were reported at and around S5 which was also the confluence of Telnala with natural stream that carrying little agricultural wastes. Enhancing of euglenoid abundance in the point might be attributed to high inorganic phosphate and nitrate content of the water samples (Table 2). Lowest representation of euglenoiods at S1 indicated that they are quite sensitive to refinery waste and escape away due to high effluent concentration.

There were oscillations in ranges of the parameters in different stations of the stream (Table 2). The water temperature ranged from $13.62^{\circ} \mathrm{C}$ at $\mathrm{S} 6$ to $31.62^{\circ} \mathrm{C}$ at $\mathrm{S} 1$ (Table 2). The $\mathrm{pH}$ of the stream water was acidic during summer to alkaline in winter. Maximum $\mathrm{pH}$ recorded was 9.4 at S1 during winter and the minimum was 5.52 at S6 during summer. Conductivity showed a wide variation in all the seven stations from $35.4 \mu \mathrm{S} / \mathrm{cm}$ at study site S6 to $392.2 \mu \mathrm{S} / \mathrm{cm}$ at S1. The concentration of DO was recorded in the range of $2.14 \mathrm{mg} / \mathrm{l}$ at S3 to $8.78 \mathrm{mg} / \mathrm{l}$ at $\mathrm{S} 6$. The lower values of DO except at S6 indicated polluted status of the entire stream (Sheela et al. 2011 and Lekwot et al. 2012). Free $\mathrm{CO}_{2}$ ranged from $1.89 \mathrm{mg} / \mathrm{l}$ at $\mathrm{S} 7$ to $21.70 \mathrm{mg} / \mathrm{l}$ at $\mathrm{S} 1$. Higher values of BOD were found at stations S2 to S4. COD ranged from $46.8 \mathrm{mg} / \mathrm{l}$ at station S6 to $216.8 \mathrm{mg} / \mathrm{l}$ at $\mathrm{S} 1$. The maximum concentration of inorganic phosphorus $(4.99 \mathrm{mg} / \mathrm{l})$ and nitrate $(2.63 \mathrm{mg} / \mathrm{l})$ were recorded at the station S6. Receiving of agricultural runoff from the adjoining fields might be attributed for overall higher values of the inorganic phosphorus and nitrate at S6. Highest values phenol and TOC recorded at S1 (phenol $1.18 \mathrm{mg} / \mathrm{l}$ and TOC $17.99 \mathrm{mg} / \mathrm{l}$ ) and showing gradual decreasing trend towards natural stream (Table 2).

Phytoplankton abundance is an important indicator of water pollution (Haldar et al. 2014). It is regulated by physical, chemical and biological characteristics of the water body (Goldman and Horne 1983). The annual mean values of phytoplankton abundance at the different sampling stations were ranged from $38.42 \times 10^{3}$ cells/l at S1 to $363.43 \times 10^{3}$ cells/l at confluence point S5 (Table 2). There was a significant temporal variation in abundance of phytoplankton observed in the stream (Fig. 2). The luxuriant growth of phytoplankton was observed during the late monsoon to post monsoon months (August to October 2011), while the lowest abundance value was recorded during winter months (December 2011 to January 2012). 


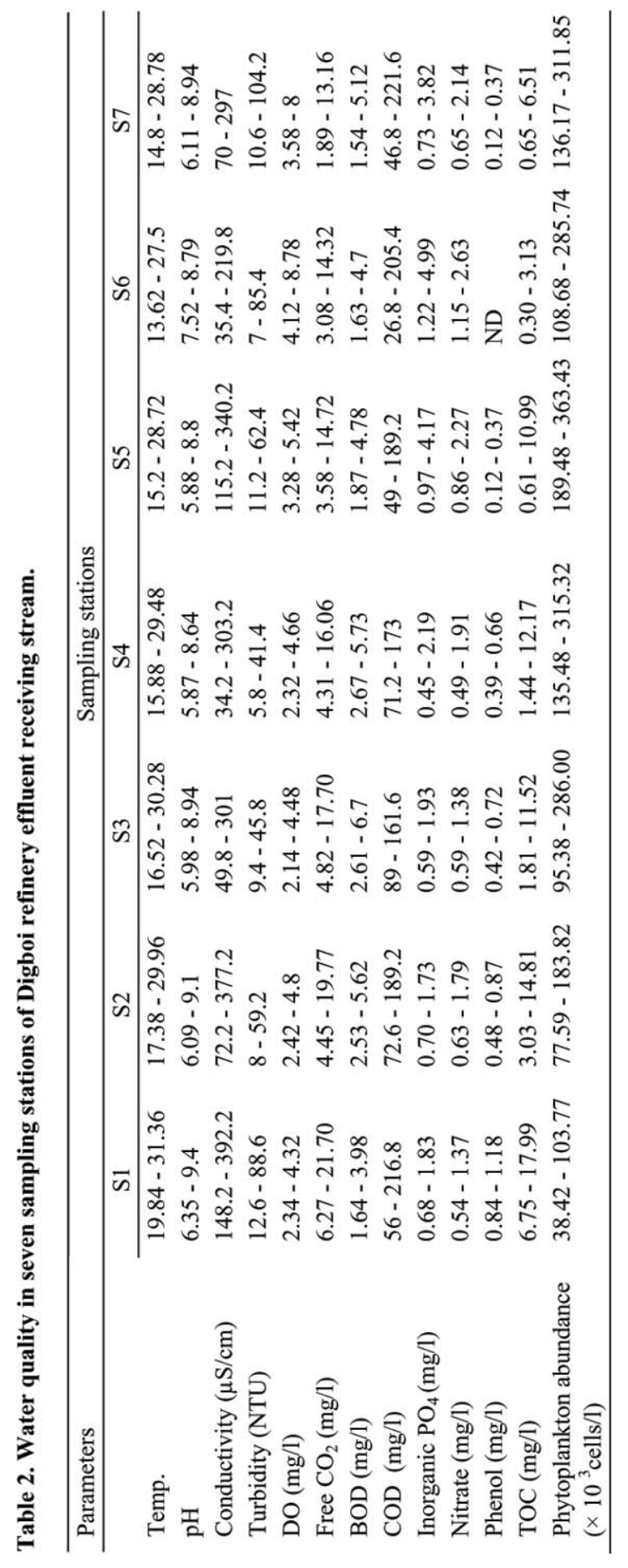


Pearson's correlation coefficient analysis made it evident that there were strong interactions between $\mathrm{pH}$, inorganic phosphorus, nitrate, phenol and total oil content with that of phytoplankton in the stream (Table 3). Increased inorganic phosphorus and nitrate content in water enhanced the phytoplankton abundance, whereas, a significantly negative relationship was observed with that of $\mathrm{pH}$, phenol and total oil content in the Telnala as well as in the stream.

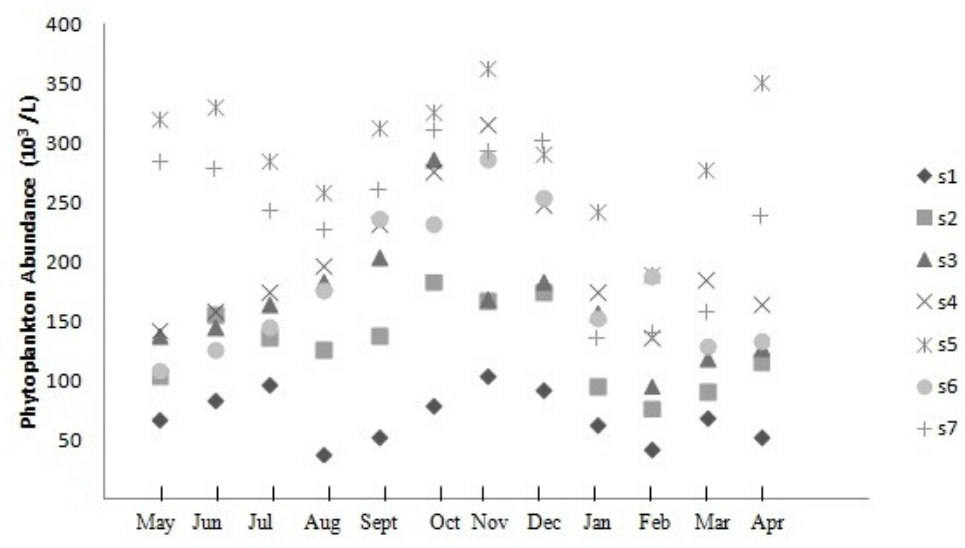

Fig. 2. Temporal variations of phytoplankton abundance at seven sampling stations along Digboi refinery effluent stream.

Table 3. Pearson correlation coefficients between water quality parameters of Digboi refinery effluent receiving stream with phytoplankton abundance during the study period.

\begin{tabular}{lc}
\hline Parameters & Phytoplankton abundance \\
Temperature & -0.028 \\
$\mathrm{pH}$ & $-0.290^{* *}$ \\
Conductivity & -0.158 \\
Turbdity & 0.022 \\
$\mathrm{DO}$ & 0.092 \\
Free $\mathrm{CO}_{2}$ & -0.128 \\
$\mathrm{BOD}$ & 0.094 \\
$\mathrm{COD}$ & -0.163 \\
Inorganic $\mathrm{PO}_{4}$ & $0.191^{*}$ \\
$\mathrm{NO}$ & $0.217^{*}$ \\
$\mathrm{Phenol}_{\mathrm{TOC}}$ & $-0.650^{* *}$ \\
\hline
\end{tabular}

${ }^{*} \mathrm{p}<0.05 ;{ }^{* *} \mathrm{p}<0.01$

\section{Acknowledgement}

The authors are thankful to the Oil India Ltd., Duliajan for partial financial support and laboratory assistance in undertaking the study. They are also grateful to Prof. M. Khondker, Dhaka University for his valuable suggestion. 


\section{References}

APHA 2012. Standard Methods for Examination of Water and Wastewater, (22 ${ }^{\text {nd }}$ ed.). American Public Health Association, Washington DC. pp. 1175.

Atici T and Obali O 2010. The diatoms of Asartepe Dam Lake (Ankara), with environmental and some physicochemical properties. Turkish J. Bot. 34: 541-548.

Baruah PP, Kakati B and Ahmed I 2009. Some Fresh Water Algae of Oil Refinery Effluent Drains of Assam, India. Our Nature 7: 139-145.

Desikachary TV 1959. Cyanophyta. ICAR Monograph, New Delhi. pp. 686pp.

Fritsch FE 1935. The structure and the reproduction of the algae. Vol. I. University Press, Cambridge. pp. 791.

Fritsch FE 1961. The structure and the reproduction of the algae. Vol II.University Press, Cambridge. pp. 791.

Gandhi HP 1998. Fresh water diatoms of central Gujrat. Bishen Singh Mahendra Pal Singh, Dehradun. pp. 324.

Goldman CR and Horne AJ 1983. Limnology. McGraw-Hill Book Company, New York. pp. 464.

Haldar S, Mandal SK, Thorat RB, Goel S, Baxi KD, Parmer NP, Patel V, Basha S and Mody KH 2014. Water pollution of Sabarmati River - A Harbinger to potential disaster. Environment Monitoring and Assesment 186: 2231-2242.

Kelly MG 1998. Use of the trophic diatom index to monitor eutrophication in rivers. Water Resour. 32: 236-242.

Lekwot VE, Caleb AI and Ndahi AK 2012. Effects of effluent discharge of Kaduna refinery on the water quality of river Romi. J. Res. Environ. Sci. and Toxicol. 1(3):41-46.

Mahadev J, Hosamani SP and Ahmed Syed Akheel 2010. Statistical multivariate analysis of lakes water Quality Parameters in Mysore, Karnataka, India. World Applied Sciences Journal 8 (11) : 1370-1380.

Mathivanan V, Vijayan P, Sabhanayakam S and Jeyachitra O 2007. An assessment of plankton population of Cauvery River with reference to pollution. J. Environ. Biol. 28(2): 523-526.

Mc Carmic PV and Cairns JJ 1994. Algae as indicators of environmental change. J. Appl. Phycol. 6: 509-526.

Palmer CM 1959. Algae in water supplies. US Department of Health, Education and Welfare, Public Health Service, Cincinnati. (Public Health Service publication No. 657).

Palmer CM 1969. A composite rating of algae tolerating organic pollution. J. Phycol. 5: 78-82.

Perumal GM and Anand N 2009. Manual of fresh water algae of Tamilnadu. Bishen Singh Mahendra Pal Singh, Dehradun. pp. 133 pp.

Prescott GW 1975. Algae of the Western Great Lake area. W Mc Brown company publishers, Iowa. pp. 977. Ramanathan KR 1964. Ulotrichales. Indian Council of Agriculture Research, New Delhi. pp. 188.

Sheela AM, Litha J and Joseph S 2011. Environmental status of a tropical lake system. Environment Monitoring and Assesment. 180: 427-449.

Singh AK and Gaur JP 1989. Algal epilithon and water quality of a stream receiving oil refinery effluent. Hydrobiol. 184: 193-199.

Smith GM 1950. The freshwater Algae of the United States. McGrew Hill Book Company, Inc. NY. Toronto. pp. 719.

Yamagishi T 2010. Planktonic algae of South East Asia. Bishen Singh Mahendra Pal Singh, Dehradun. pp. 235. 